垣内 隆

\title{
A Village of Electroanalytical Chemistry
}

\section{Takashi Kakiuchi}

「村社会」という言葉が明確に定義され たものとしてあるのかどうか、調べてはい ないが、たとえば市民社会では通用しない 不合理ないしは非合理な約束事や決まりが 通用する閉鎖的環境、という意味で使われ ることが多いように思われる。古くからの 習わし、習俗として、あるいは文化として そういうことが定着している場合もあるが、 この言葉は、それよりは否定的な意味合い を帯びている。

今年の 3 月 11 日の東日本大震災を引き 金とする福島第一原発の事故は、未だに終 息はもとより収束の見通しも立たず、一方、 それが引き起こした被害の甚大さが、あち らこちらで次々に表れてきている（注 1）。 この事故の結果として明るみに出てきたも のは多いが、その一つが原子力村というも のの存在であった。原子力発電開始以来の 約半世紀の間に作り出されてきたこの産・ 官・学をまたぐメガスケール村社会は、発 電能力にして日本の発電容量の $20 \%$ \%ま り、50 基以上の発電用原子炉を造り出した だけではなく、テレビのコマーシャル、学 校の副読本、地域社会のスポンサー活動な どを通して、社会の隅々にまで浸透してき ていた。そして、「原子力発電はクリーン エネルギー」、「原子力発電は低コスト」、 「5 重の防護壁で安全」、等々の「神話」 を発信してきたのである。
3 月 11 日以降、原子力村の現状・政策追 認型・合目的的科学観とでもいうべき価值 観、というよりもより正確にはそうした普 遍性の意識を欠いたプラグマチズムによる メガ仲間環境が、如何に一面的で自分勝手 なものであったかということが、その全貌 は未だ不詳であるにしろ、大筋としては人 前にさらけ出されたといえるだろう。

しかし、仲間内でだけ通用する規範で互 いにほめ合い、それによって満足を得ると いうのは、原子力村に限ったことではない。 学会というものが、学術領域のある範囲を 限定し、その分野で共有しうるコンセプト をべースに形成されているのであるから、 そうした学会は常にこの危険性を君んでい る。

この危険性をもう少し詳しく定義するな ら、まず第一に、仲間意識が科学的合理性、 批判的精神に優越することである。このこ とは、たんなる趣味の会であれば、全く問 題にならない。しかし、学会がそれらと区 別されるところのものは、最近、忘れてい るケースがしばしばあるように思えるが、 学会の要は言うまでもなく「学」あるいは 「科学」である。ここのところが趣味の会 はもとより、「産」とも「官」とも異なる ところである。

危険性の第二は、すこし角度がずれるが、 その学問領域の同時代性である。これは 
ケージ効果あるいは慣性いや惰性の法則の ようなもので、篭の中では自己充足してい るが、その䈕そのものが社会的には置き去 りになっている、というものである。科学 的価值はおそらく不変であるが、無数の価 值のなかでの特定の科学的価值の相対的な 重要性は時代とともに変遷する。その学会 の領域がどの程度の社会的な関わりを持っ ているかによって、その学会の損なわれた 価值が社会的に影響を与える程度は、もち ろん異なる。しかしながら、学会がその時 代に生きる人たちによって構成され、その 時代に存在している以上、篭の外の流れと 切り離されては存立し得ないから、これら の危険性に意識的であれ無意識的であれ適 切に対応していなければ、その学会の存立 はあやしくなる。

マイクロスケールあるいはナノスケール 学会であるポーラログラフ学会は、いかな る電気分析化学村を形成しているのか。

本会の討論会では、率直に意見を述べる ことが、ある程度は根付いている。私の経 験では、初めて本会の討論会に出たとき だったか、玉虫伶太先生、松田博明先生ら が㛜しいコメントをされていたように覚え ている。吸着エネルギーの発表をした時は、 佐藤弦先生が キロジュールの K は 小文字 ですと、㛜しくご指摘してくださった。あ る先生が電極反応速度について発表された のに対して、その佐藤弦先生が「初めから そう言う研究はおやりにならない方が良 かったのでは」というコメントをされて、 たいへん驚いたこともあった。そうした諸 先輩が作り出された科学に照らしての自由 で批判的な精神が、今の討論会の雾囲気に つながっているように思われる。これはも ちろん「学」を担保する側に寄与する。

それでは、ケージ効果ないし惰性の法則 の方はどうだろうか。 8 月 20 日から 3 日間、
長春で開催された The Thirteenth International Symposium on Electroanalytical Chemistry (13 ${ }^{\text {th }}$ ISEAC) は、 500 人以上の参加で盛況であった。発表の 大半は、納米（ナノ）微粒子やグラフェン などのマテリアルズ、バイオセンシングの ための官能素子とそれを組み込む新しいプ ラットフォームに関するもので、各分野で の最先端の成果を電気分析化学に積極的に 取り入れようとする姿勢が目立った。ここ では、確かに電気分析化学を時代に沿って 動かそうとしている。しかし、その一方、 たとえばそうした修飾電極、機能性電極に おける反応の定量的解析を行ったものは皆 無であった。動かしているうちに篭がなく なっている、あるいは初めからなかったの か。討論がさほど活発ではなかったのは、 素材の多様性とその組み合わせがもたらす 無限の可能性が、批判することを無とする 側に働いているということもあるのだろう。

これに対して本会は、篭の中に閉じこ もっているのか、それとも、逆にこちらか ら今の流れに提案する、あるいはあたらし い流れを作る方向に動き得ているのか。今 年限りの会長が今頃になって言うのも変だ が、後者であることを意識的に追求した村 作りをしなければならないし、そうできる のではないかと思い始めている。

注 1： 本稿を書いている 8 月 30 日の報 道で目につくのは、「土壤污染、34 地点が チェルノブイリ移住基準超」（読売新聞）、 前日だと「ワカサギから放射性セシウム二 赤城山の大沼一群馬県」（時事通信）、

「葛飾の馬ふん堆肥から許容值超えるセシ ウム」(産経新聞) など。

（かきうち・たかし、本会会長） 